\title{
Management Accounting Research Approaches: A Critical Review
}

\author{
Achchi Mohamed Inun Jariya ${ }^{1} \&$ Thirunavukkarsu Velnampy ${ }^{2}$ \\ ${ }^{1}$ Department of Accountancy and Finance, Faculty of Management and Commerce, South Eastern University of Sri \\ Lanka, Oluvil, Sri Lanka \\ ${ }^{2}$ Department of Accountaning, Faculty of Management Studies and Commerce, University of Jaffna, Jaffna, Sri \\ Lanka \\ Correspondence: Achchi Mohamed Inun Jariya, Department of Accountancy \& Finance, Faculty of Management and \\ Commerce, South Eastern University of Sri Lanka, University Park, Oluvil, \#32360, Sri Lanka. Tel: 94-77-710-5988. \\ E-mail: jariyaam@seu.ac.lk
}

Received: July 22, 2020

doi:10.5430/ijfr.v12n1p129
Accepted: September 1, 2020

Online Published: December 24, 2020

URL: https://doi.org/10.5430/ijfr.v12n1p129

\begin{abstract}
The management accounting field uses three research approaches: mainstream, interpretive and critical. These paradigms involve employing distinct research methodology whilst studying topics related to management accounting. The distinction in research methodology was made based on assumptions about the nature of social science and nature of society. Various scholars had used those assumptions to categorise research prototypes. Among them, the frameworks developed by Burrell and Morgan (1979), Hopper and Powell (1985, Chua (1986) and also Rayan and Scapens (2002) are all noteworthy. Therefore, the aim of this study is to critically review these frameworks as a way to identify their similarities and differences among them. On the basis of the review, it is observed that perspectives of management accounting were originated from an extremely long means of travel, and there are lots of similarities and significant differences among the frameworks reviewed.
\end{abstract}

Keywords: nature of social science, nature of society, mainstream, interpretive, critical

\section{Introduction}

Management accounting research has drawn the attention of many scholars of accounting, and numerous studies have been conducted and various organisational theories, for instances contingency theory of management accounting and institutional theories, are suggested. This is because management accounting and management accountants are understood by both scholars and practitioners as strategic partners at the organisational team within their organisational process, both contributing to building value into the organisation by managing the resources, operations and people to accomplish its goals (Hilton, 2001). Langfield-Smith and Baines (2003) added that managers require information as a way to create both operational and strategic decisions within a busy environment throughout the appropriate usage of management accounting practices. Moreover, an organisatin's accounting information system plays an important part in improving the organisational performance by offering relevant information (Haleem et al., 2020).

Since the 1970s, attention in the advancement of diverse perspectives on accounting studies has increased, although it has also been criticised: for example, absence of accounting theory within the organisational practices has been pointed out. Various schools of thought have now been presented with various approaches for understanding the accounting nature in a broader institutional and sociological context. Different perspective on accounting resulted in the usage of different methodological approaches in accounting research.

The development of different schools of thoughts within social and institutional characteristics, particularly, Hopper and Powell (1985), Chua (1986) and Ryan and Scapens (2002), attracted in the philosophical framework created by Burrell and Morgan (1979). For that reason, this article is meant to critically review the frameworks developed by Hopper and Power (1985), Chua (1986) and Ryan and Scapend (2002) beginning from Burrell and Morgan's (1979) framework. The similarities and differences among those frameworks will also be presented.

The reminder of the article is arranged at a sequential arrangement of each framework is developed. Thus, first four sections have been devoted to review the frameworks evolved from Burrell and Morgan (1979), Hopper and Powell (1985), Chua (1986) and Ryan, and Scapens (2002). Conclusion is offered at the final section. 


\section{Critical Review of Different Frameworks}

\subsection{Burrell and Morgan's (1979) Framework}

Burrell and Morgan (1979) developed their framework based on the 'objective' and 'subjective' dimensions, which are independent. By integrating these two dimensions at the two extreme ends in their framework as presented in Figure 1, Burrell and Morgan (1979) explored their philosophical discourse on the basis of two groups of assumptions: "(i) the nature of social science and (ii) the nature of society". Social science assumption is further conceptualized concerning four different interrelated basics. They are the assumptions of 'otology', epistemology', 'human nature' and 'methodology'.

'Ontology' is concerned with the nature of "reality" (the core of phenomena under investigation), where there are assumptions of objective and subjective position. The assumption of the objective position is independent of human cognition, i.e. reality is the concreate construction outside and before the individual mind. Contrarily, the assumption of ontology's subjective nature is that reality is an object of personal cognition, i.e. truth is a personal mental construct.

"Nature of knowledge about what forms it takes and how it can be obtained and transmitted" is meant to be 'epistemology'. On one extreme, the objective interpretation of epistemology is something that must be gained through observation and fragmented. In other words, there is a theory that must be considered true if it is not to be falsified again and again by experimental events. On the other extreme, subjective view presupposes that knowledge is something to be experienced personally. This view on the acquisition and transmission of knowledge is fundamentally personal in nature, i.e. the social world can only be understood by acquiring knowledge of the subject under investigation.

The subjective - objective dimension

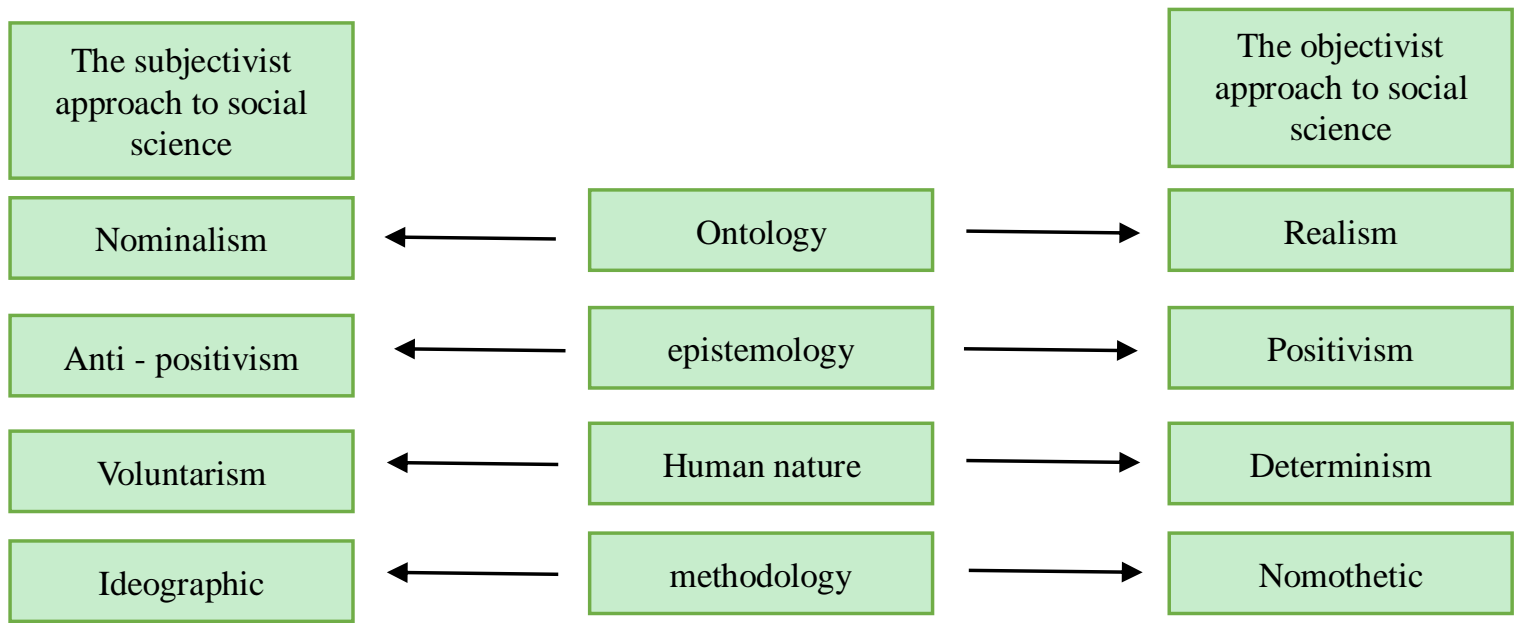

Figure 1. A Scheme for analyzing assumptions about the nature of social science

(Adapted from Burrell and Morgan, 1979, p. 3)

Ontology and epistemology assumptions are related to the assumptions of human nature although conceptually they are different. Human nature refers to the association between human and their environment. The position of human attitudes can be recognized in a dynamic or deterministic way (objectivism), which considers man and their experiences as the product of external environmental forces on the one hand. People, on the other hand, can be regarded in a biliteral way (subjectivism), which believes that man has autonomy, a more creative character, free will and the ability to make choices and create and interpret his own environment as a controller.

All three set of assumptions mentioned above have direct stimuli of a methodological nature. The appropriate research methods for collecting valuable evidence is referred to as methodological assumptions. If both social and 
physical or natural worlds are same, methods derived from the natural sciences are used to detect, interpret and predict social norms. Then, hypothesis testing and analysis of collected data using standard research tool like questionnaire will be with the practice of statistical techniques. Otherwise, when the individual subjective experiences and social world creation are emphasized, knowledge is most appropriately gained through understanding by the inner world of the individual (e.g. in-depth interviews and participant observation).

The nature of society is the second dimension of Burrell and Morgan (1979). The characteristics of this dimensions are order and conflict view of society. The order is one of consistency, integration, functional integration and consensus. The other approach efforts on alteration, struggle, fragmentation and intimidation.

Burrell and Morgan (1979) combined the two dimensions, which are independent from each other, in order to form four frames of reference namely; "(i) functionalist, (ii) interpretive, (iii) radical humanist and (iv) radical structuralist". These four paradigms are mutually exclusive and determined based on the nature of social science and society assumptions (Burrell \& Morgan (1979). Refer the Figure 2.

Burrell and Morgan's (1979) functionalist view is the leading paradigm delivered for conducting educational sociology and organisational research. It is very practical and extremely engrained within the approaches and regulation of sociology and its meaning is on the view of objective point. The concept they used to classify the sociology of regulation are applicable to all schools of thoughts within the paradigm at varying degrees. Characteristics of a functional paradigm is on condition that "expiations for status qua, social order, consensus, social integration, solidarity, need satisfaction and actuality". Functionalist traits allow researchers to exist as truthful, positive, settled and nominal. It takes coherent human achievement and trusts that an individual could realize society throughout observations using problem based in a very practical way. Furthermore, the assumptions strongly emphasize the importance of understanding order, balance, social stability, effective "discipline' and control of social privileges with respect to social change. Functionalist view is the dominant paradigm dominates the management accounting research (e.g. Hopper \& Powell, 1985; Chua, 1986; Ryan, Scapens, 2002).

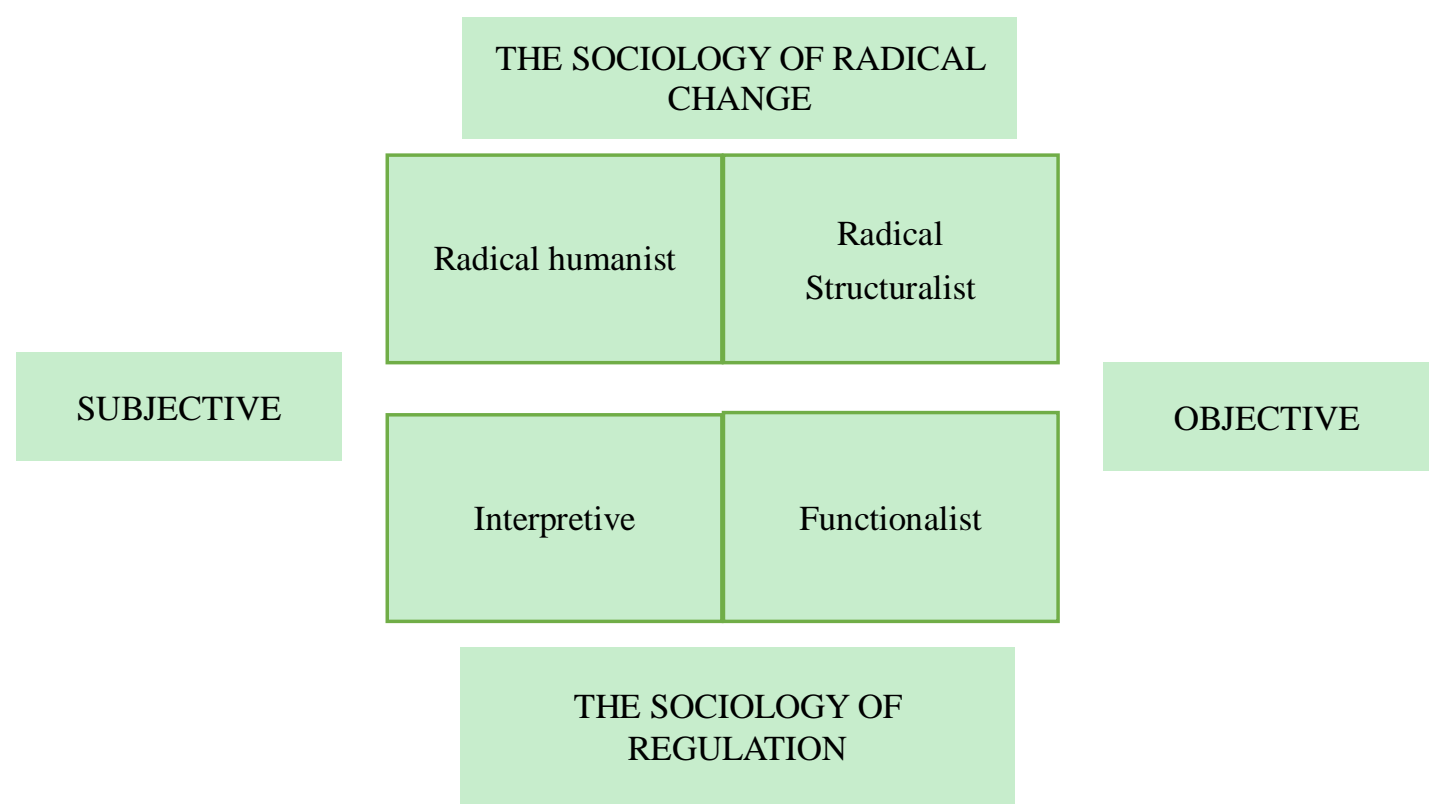

Figure 2. Four paradigms for the analysis of social theory

(Adapted from Burrell and Morgan, 1979, p. 22)

"Interpretive" paradigm exemplified by Burrell and Morgan (1979) had been described as "the sociology of regulations (subjective regulation)". This is because the analysis of the social world is often at the level of subjective experience and implicitly understand the world. In this paradigm the researchers' understanding of social world and subjective as an emerging social process within the framework of which the individual perceives and participates are formed by the involvement of individual. 
Third paradigm represented by Burrell and Morgan's (1979) framework is "radical humanistic" which was interested in evolving the sociology of radical change from a subjective transformational standpoint. The theorists in this paradigm are concerned with publishing the limits of existing social arrangements. They found current hegemonic ideologies to separate individuals from their "true personality". This paradigm was used to validate the longing for radical variations based on the scope of large anti-organisation. Burrell and Morgan's (1979) final paradigm is the "radical structuralist". Theorists located inside in this final paradigm (objective-radical change) focus on "structural relationship in a realistic world".

\subsection{Framework of Hopper and Power (1985)}

Hopper and Power (1985) formed their framework as a tool to assemble and evaluate the researches in accounting within social and organisational aspects, considering the importance of the primary theoretical and philosophical assumptions of Burrell \& Morgan (1979). However, the model developed by Burrell and Morgan dealt only with the "subjective-objective" dimensions of social science and there are some other aspects also to be considered while considering a research (Hopper \& Powell, 1985). Although the dimension related to social science assumptions is formed as a continuum, Hopper \& Powell (1985) pointed out that when distinguishing aspects of the social sciences, Burrell \& Morgan (1979) created a space between "objective and subjective" approaches. Hopper and Powell (1985) further divided the organisational and social aspects of Burrell and Morgan continuously considering the dimensions (1979) into another three groups as the continuity of Burrell \& Morgan (1979). They are functional, interpretive and radical. Functionalist and interpretive are included within the Burrell \& Morgan's frames of reference. Theories which are under functional category treat the system as static empirical phenomena, where management theories can be obtained by systematically studying cause and effect relationships and situational variables when looking at employee behaviour (Hopper \& Powell, 1985).

Hopper and Powell's (1985) functional scenario was additionally subdivided as social system theory, objectivism and pluralism. Objectivism considers human nature to be rational, controllable and predictable. According to Hopper and Powell (1985) conservative management accounting practices are grounded from this approach and decision-making accounting information is limited with financial estimates for disclosing profit maximizing opportunities. Furthermore, under this view Hopper \& Powell (1985) states that management accounting researchers took the real position of monetary concerns and managerial relations through which accounting systems are modeled.

On account of the limitations of objectivism and additional institutional factors related to humans' social nature, many accounting studies tend to look at the theory of social system and its meaning. Hopper and Powell consider optimism about the functioning of the human organ in a management accounting system that does not operate under the open system theory approach, and is related to the principles of institutional bureaucracy failures by Burrell \& Morgan (979). This approach assumes that accounting systems are the result of human social nature and additional organisational factors. This approach includes psychology, social psychology theories, structural theories, open system theory and contingency theory. Under this view, Hopper \& Powell (1985) realized that management accounting research had been developed with similar assumptions about the social sciences and nature of society. They further emphasized that contingency theory is a complete example of functional view in preference to a main new departure. In addition, both social systems and objectivists approaches strain guidelines to reach order and balance in a monopoly and basically administrative approach to organisational performance, although neither social system nor objective approaches significantly solve problems of power and conflicts.

Thus, in terms of pluralism, Hopper \& Powell (1985) consider industrial relation as the most obvious of the problems of power, conflict and sectarian interest, and the assumption of monopolistic organisational goals that are irrelevant. In other words, companies are considered to be segmented groups with different and often conflicting goals. Since groups are interdependent there is only one common purpose. Control within organisation is accomplished through sustaining system of guidelines and procedures which allow negotiation in between groups, and each group is governed by other groups (Hopper \& Powell, 1985). Pluralism does not comply with the main vies of neoclassical economics namely rational decision- making, profit maximisation at the margin or long run equilibrium.

This world is considered to be made up with objects of external, independent and relationship being opposed to functionalist theories which people acknowledge are controlled by the social world in which they live, interpretive theories are primarily about personal sense and "people's perceptions of reality" rather than any independent "reality: outside of them (hopper \& Powell (1986). Further, social structure such as systems are frequently viewed as object-oriented, and therefore provide the power of thought and action under the functionalist approach, while on the other hand an interpretive approach underlies subjectivity in terms of the social world and seeks to recognize it mainly from reference frame of those being studied (Hopper \& Powell, 1985). 
Hopper and Powell (1985) stated that interpretive approach evaluates the social realities as people constantly interacting with social realities and sutured with society. Furthermore, they renowned that the work of interpretive theories in underlining the social formation of accounting is interesting and how the meanings attached to it help to maintain the status quo.

However, radical theories reject the status quo. Without questioning broad social relations such as power and class relations, status quo was indirectly accepted and essentially supported by functional and interpretive theories (Hopper \& Powell, 1985). Society is made up of contradictory components and spread by power structures that urge the dissimilarities and estrangements in all parts of life; they are interested in evolving the considerations of the social and economic world, which also create a critique of status quo rather than functional and interpretive approaches.

Furthermore, Hopper and Powell (1985) argue that adoption of managerial reference frame and the support for status $q u o$ are accepted in the consideration of traditional accounting theory. Thus, according to Hopper and Powell (1985), the critical refrain of all radical theories.

Thus, according to Hopper \& Powell (1985) the principles nature and organisation of a society as a whole reflects and shapes every aspects of the society are the essential theme of all radical theories. As a result, no part of a capital society can be completely comprehended without a full understanding of capitalism. Therefore, an important fragment of capitalist society is the accounting system, and accounting and capitalism are independent.

The contribution of Hopper and Power (1985) to the literature by reviewing researcher' concerns on the most significant fundamental issues in accounting research, by reviewing previous empirical works with in the frame of functional, interpretive and radical perspective and each of these group is structured as shown below in figure 3 within the framework of Burrell and Morgan (1979).

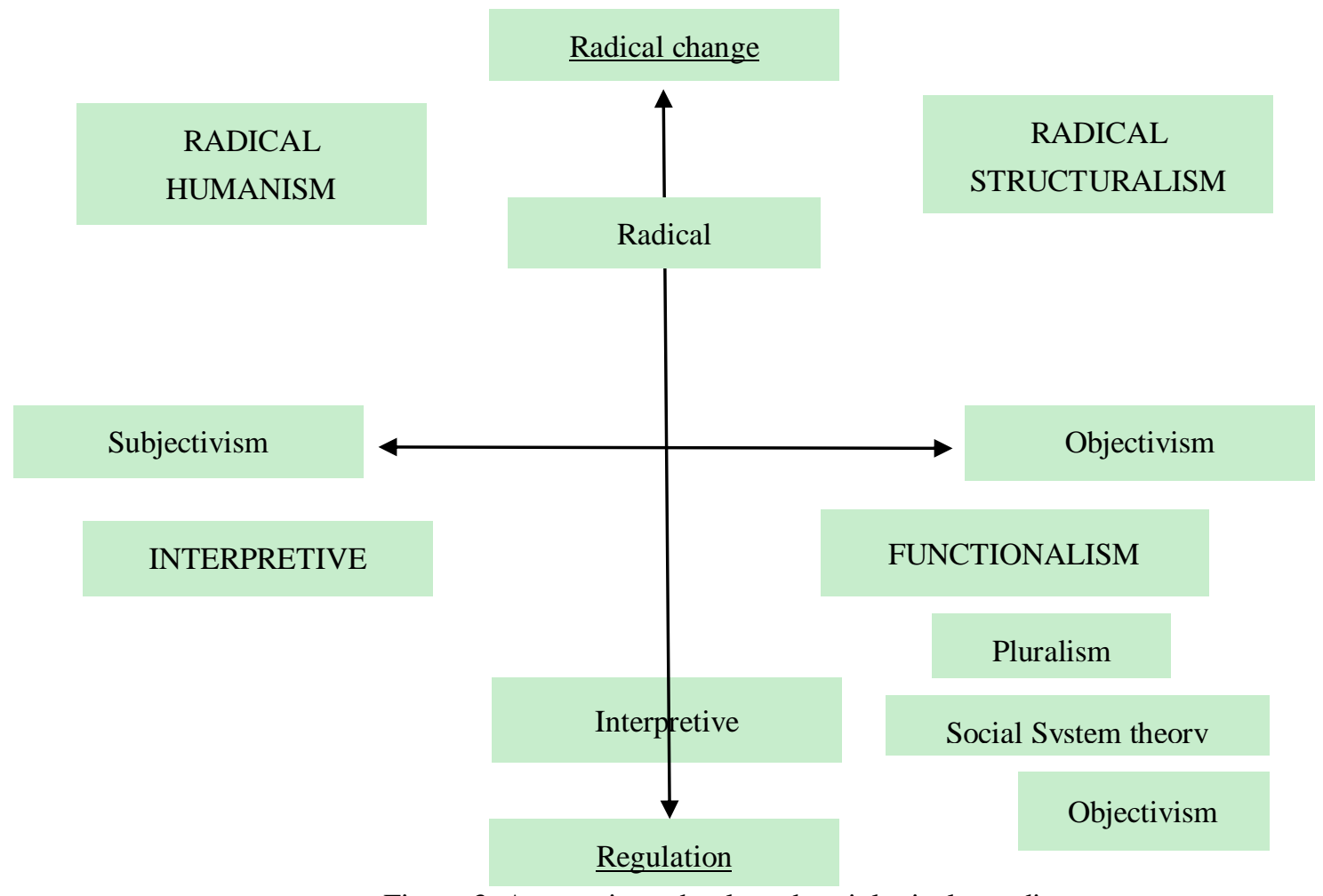

Figure 3. Accounting schools and sociological paradigms

(Adapted from Hopper and Powell, 1985, p. 432)

\subsection{Framework of Chua (1986)}

Another notable work is the radical advances in accounting thoughts revealed by Chua (1986). This framework expanded the "mainstream" research in management accounting together with "interpretive" and Critical" research. 
Chua (1986) rejects the notion of Burrell \& Morgan (1979) framework that they are (i) the use of mutually exclusive contradictions (determinism Vs. voluntarism); (ii) their misconception of Kuhn as supporting irrational paradigm choice; (iii) the latent relativism of truth and reason promotes their framework; (iv) the skepticism of the differences between radical structuralist and humanist paradigms. In addition, Chua found that there was a problem in framework that had not been altered from the sociology, indicating some balance between two disciplines. Excluding a thorough appearance of such commonalities and the problems quoted above, without following the Burrell and Morgan framework, Chua (1986) distinguished accounting perspective on the basis of three sets of assumptions: : "(i) beliefs about the nature of knowledge (epistemology an methodology), (ii) beliefs about physical and social reality (the empirical phenomena under study - ontology) and (iii) the belief about the relationship between theory and practical world of human affairs, more specifically, between accounting theorizing and organisational practice. Chua (1986) combined these assumptions and categorized the approaches of management accounting research into three at the level of discipline rather than at the level of individual research project. They are mainstream, interpretive and critical accounting research. Chua (1986) pointed out that interpretive and critical perspective are the alternative approaches to management accounting research. Chua (1986) summarized the differences among the three approaches and their underlying assumptions as shown in Table 1.

Conventional accounting assumptions are related to "interpretive in nature" and "critical by substance" which are summarized inside Table 1. Specifically, Chua (1986) argues for creating and evaluating the merits and demerits of the assumptions of four research paradigms, and Burrell \& Morgan (1979) argues for mutual uniqueness of those paradigms within the context of management accounting research.

Though, Chua (1986), in her article combined different research traditions with the focus facilitating the description of research in management accounting towards paradigm diversity, she did not emphasize their exclusivity very clearly and she simply put forwarded two alternative perspectives as most favorable.

Table 1. Assumptions of management accounting perspectives

\begin{tabular}{|c|c|c|c|}
\hline Assumptions & Mainstream & Interpretive & Critical \\
\hline $\begin{array}{l}\text { Belief about } \\
\text { knowledge }\end{array}$ & $\begin{array}{l}\text { Theory is different from } \\
\text { annotations that can be used to } \\
\text { attest or disprove a theory. } \\
\text { Hypothetic logical reasons of } \\
\text { scientific clarification } \\
\text { recognized. } \\
\text { Data collection and analysis is } \\
\text { quantitative which permits } \\
\text { generalisation. }\end{array}$ & $\begin{array}{l}\text { Scientific clarifications } \\
\text { of human purpose } \\
\text { required. } \\
\text { Their capability is } \\
\text { evaluated by the norms } \\
\text { of rational reliability, } \\
\text { subjective explanation } \\
\text { and congruence with } \\
\text { performer's usual - } \\
\text { sense clarification. } \\
\text { Ethnographic work, case } \\
\text { studies and participants } \\
\text { observation stimulated. } \\
\text { Performers studied in } \\
\text { their daily life. }\end{array}$ & $\begin{array}{l}\text { The norms for } \\
\text { determining theories are } \\
\text { tentative and contextual. } \\
\text { Ethnographic, historic, } \\
\text { and case study research } \\
\text { are mostly used. }\end{array}$ \\
\hline $\begin{array}{l}\text { Belief bout } \\
\text { physical and social } \\
\text { reality }\end{array}$ & $\begin{array}{l}\text { Experiential reality is } \\
\text { objective and outside the } \\
\text { subject. } \\
\text { Humans are also classified as } \\
\text { submissive objects: not } \\
\text { understood as social reality } \\
\text { creators. Single aim of } \\
\text { utility-enhancement } \\
\text { considered presumed of } \\
\text { individuals and organisations. } \\
\text { Means-end rationality is } \\
\text { considered. }\end{array}$ & $\begin{array}{l}\text { Social reality emerges, is } \\
\text { created subjectively, is } \\
\text { objectified by human } \\
\text { interface. } \\
\text { All activities have } \\
\text { meaning and purpose, } \\
\text { are subject to } \\
\text { reconsideration and are } \\
\text { grounded in } \\
\text { socio-historical } \\
\text { practices. } \\
\text { Social order is }\end{array}$ & $\begin{array}{l}\text { Humans have internal } \\
\text { capabilities through a } \\
\text { controlling mechanism } \\
\text { (which prevents them } \\
\text { from full expression). } \\
\text { Objective can only be } \\
\text { realized over a study of } \\
\text { their historic expansion } \\
\text { and the total } \\
\text { transformation of the } \\
\text { relationship. } \\
\text { Experiential reality is }\end{array}$ \\
\hline
\end{tabular}




\begin{tabular}{|c|c|c|c|}
\hline & $\begin{array}{l}\text { Humanities and firms are } \\
\text { basically stable; } \\
\text { dysfunctional" conflict can be } \\
\text { accomplished over the design } \\
\text { of suitable accounting control. }\end{array}$ & $\begin{array}{l}\text { considered. } \\
\text { Conflicts are } \\
\text { intermediated by } \\
\text { communal arrangements } \\
\text { of social meanings. }\end{array}$ & $\begin{array}{l}\text { categorized by objective, } \\
\text { actual relations which } \\
\text { are altered and repeated } \\
\text { by subjective } \\
\text { explanation. } \\
\text { Human purpose, } \\
\text { rationality and agency } \\
\text { are putative, nonetheless } \\
\text { this is censoriously } \\
\text { investigated on the basis } \\
\text { of misconceptions and } \\
\text { beliefs in ideology. } \\
\text { The basic conflict is } \\
\text { prevalent to society. } \\
\text { Conflict ascends due to } \\
\text { prejudice and ideology } \\
\text { within social, political } \\
\text { and economic spheres, } \\
\text { which vague the } \\
\text { innovative element in } \\
\text { people. }\end{array}$ \\
\hline $\begin{array}{l}\text { Relationship } \\
\text { between theory and } \\
\text { practice }\end{array}$ & $\begin{array}{l}\text { Accounting stipulates } \\
\text { boundless. Acceptance of } \\
\text { abiding organisational } \\
\text { structure }\end{array}$ & $\begin{array}{l}\text { Theory seeks only to } \\
\text { clarify achievement and } \\
\text { to comprehend how } \\
\text { social order is created } \\
\text { and reproduced. }\end{array}$ & $\begin{array}{l}\text { Theory has a censorious } \\
\text { imperious: the } \\
\text { recognition and } \\
\text { eliminating of dominion } \\
\text { and ideological practice }\end{array}$ \\
\hline
\end{tabular}

(Adapted from Chua, 1986, pp. 611, 615 \& 622)

\subsection{Framework of Ryan and Scapens (2002)}

Moreover, taxonomy of management accounting research is also advocated by Ryan \& Scapens (2002) based on Burrell \& Morgan's (1979) framework. Ryan \& Scapens (2002) argues that "accounting research cuts across many boundaries, understanding and appropriately using the right paradigms will go a long way in developing good accounting theories". Drawing on Burrell \& Morgan's (1979), they constructed accounting research into mainstream, interpretive and critical accounting and elaborated their taxonomy of management account research as shown in the figure 4. Ryan \& Scapens (2002) argue that knowledge is derived from observation, and that a positive approach is appropriate when human behaviour is deterministic and the view of reality is firm and objective. This is meant to be mainstream research of management accounting to Ryan \& Scapens (2002). Drawing from Burrell \& Morgan (1979) model Ryan \& Scapens (2002) looks at the interpretive approach to understanding the problem of "social nature of accounting" under enquiry in terms of human behaviour supposed to be behind human actions. Rayan and Scapens (2002) classified the studies in management accounting, which have the main purpose of inferring and understanding management accounting as a social practice and as the perspective of interpretive. Ryan and Scapens (2002) demonstrated the need to examine current practices in the context of historical, economic, social and organisational contexts in order to conduct interpretive study in management accounting. 


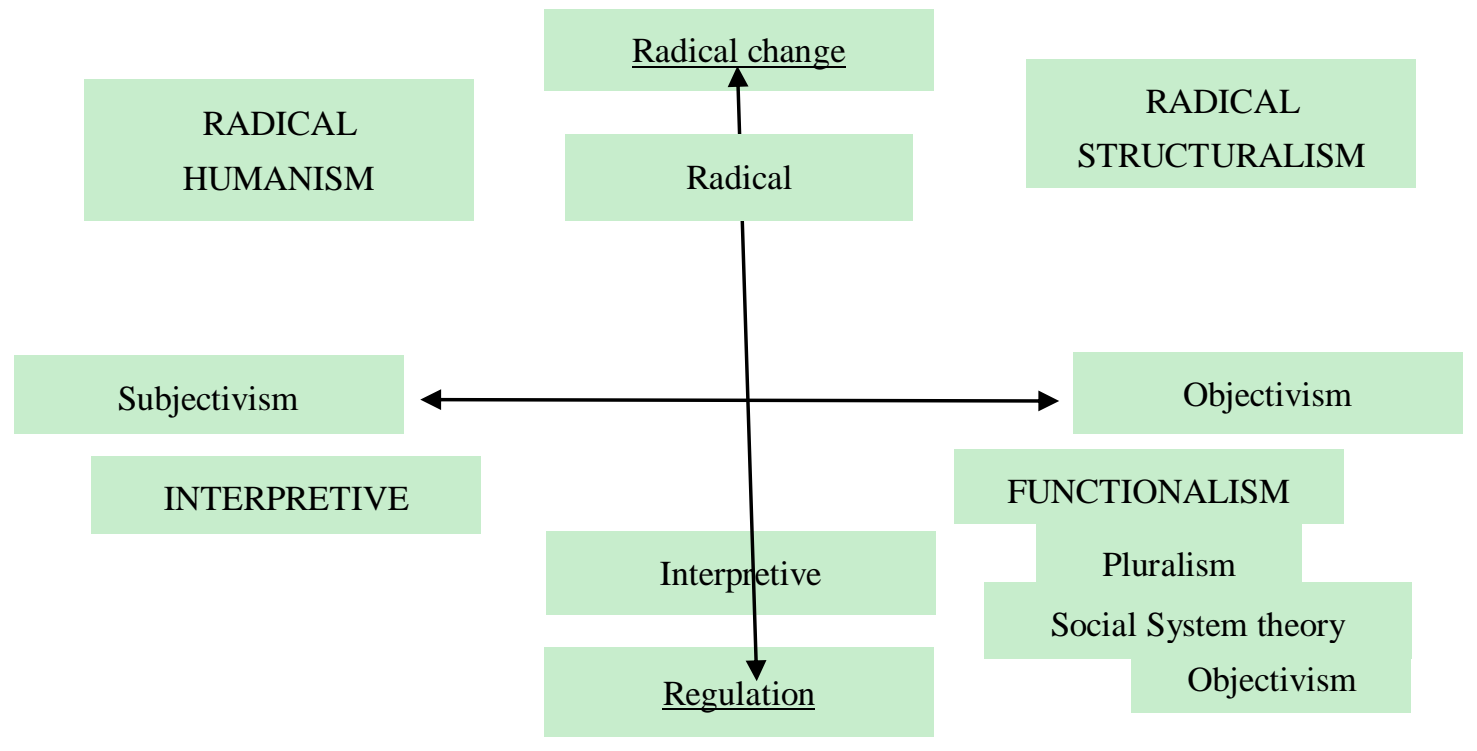

Figure 4. Taxonomy of management accounting research

(Adapted from Ryan and Scapens, 2002. p. 40)

\section{Discussion}

Based on the above critical review, it can be observed that perspectives of management accounting originated out of a very long means of travel, as Ryan \& Scapens (2002) accounting research transcends many boundaries and goes a long way in developing good accounting principles for understanding and applying the right paradigms. Accounting theories are compiled as mainstream, interpretive and critical accounting research approaches by Hopper \& Powell (1985), Chua (1986) and Ryan \& Scapens (2002). When comparing and reconciling all three approaches with that of the framework of Burrell \& Morgan (1979), it is revealed that the Hopper \& Morgan's (1979) functionalist research paradigm and the mainstream research paradigm in Chua (1986) and Ryan \& Scapens (2002) are constant with each other. Interpretive paradigm looks similar to all the four frameworks described above. The radical humanist and radical structuralist of Burrell \& Morgan (1979) frameworks are categoried as the critical accounting research paradigm under the frameworks of Hopper \& Powell (1985), Chua (1986) and Ryan \& Scapens (2002).

\section{References}

Burrell, G., \& Morgan, G. (1979). Sociological Paradigms and Organisational Analysis. London: Heinemann.

Chua, W. F. (1986). Radical Developments in Accounting Thought. The Accounting Review, 61(4), 601-632.

Haleem, A., Nawaz, S. S., \& Ayoobkhan, A. L. M. (2020, March/April). Determinant of Contingency Factors of AIS in ERP System. TEST Engineering and Management, 83, 6593.

Hilton, R. W. (2001). Managerial Accounting (4th ed.). McGraw-Hill.

Hopper, T., \& Powell, A. (1985). Making Sense of Research into the Organisational and Social Aspects of Management Accounting: A Review of its Underlying Assumptions. Journal of Management Studies, 22(5), 429-465.

Langfield-Smith, K., \& Baines, A. (2003). Antecedents to Management Accounting Change: A Structural Equation Approach. Accounting, Organisation and Society, 28(7-8), 675-698.

Ryan, B., \& Scapens, R. (2002). Research Method and Methodology in Finance and Accounting. London: Thomson.

\section{Copyrights}

Copyright for this article is retained by the author(s), with first publication rights granted to the journal.

This is an open-access article distributed under the terms and conditions of the Creative Commons Attribution license (http://creativecommons.org/licenses/by/4.0/). 